\title{
Clinical Profile of TB in Children at Pediatric Outpatient Clinic Hasan Sadikin Hospital Bandung 2016
}

\author{
Fadiya N Soekotjo*, Sri Sudarwati**, Anggraini Alam** \\ * Faculty of Medicine Padjadjaran University \\ ** Pediatric Department Faculty of Medicine Padjadjaran University \\ Jl. Prof. Eyckman No. 38 Bandung 40161 Indonesia \\ Email: fadiyans88@gmail.com
}

\begin{abstract}
The diagnosis process of TB in children is complicated. Bacteriological exam is needed to establish diagnosis, but it is not possible to be done in children. Clinical symptoms are the main criteria for TB diagnosis in children. This study aimed to provide clinical profile of TB in children and was conducted using descriptive design. The data was taken from medical record of children with TB at RSHS pediatric outpatient clinic from January 2016 to December 2016. We collected 104 subjects using simple random sampling method. We found out that 64 subjects (61.54\%) was diagnosed as lung TB and 40 (38.46\%) with extra-pulmonary TB. Contact with the source of transmission was found in 33 patients $(60 \%)$. We found that clinical symptoms of the subjects were fever $\geq 2$ weeks (62.5\%), weight increase difficulty (49\%), lymphnode enlargement (36.5\%), cough $\geq 2$ weeks (14.4\%), chest tightness (7.7\%), bone swelling (4\%), and night sweats (2\%). We concluded that clinical symptoms that are found mostly in children with $T B$ are fever $\geq 2$ weeks, weight increase difficulty, lymphnode enlargement, cough $\geq 2$ week, chest tightness, bony swelling, and night sweats.
\end{abstract}

Keywords: clinical profile, tuberculosis, TB infection in children 


\title{
Profil Klinis Pasien TB Anak di Poli Rawat Jalan Rumah Sakit Dokter Hasan Sadikin Bandung Tahun 2016
}

\author{
Fadiya N Soekotjo*, Sri Sudarwati**, Anggraini Alam** \\ *Fakultas Kedokteran Universitas Padjadjaran \\ **Departemen Ilmu Kesehatan Anak Fakultas Kedokteran Universitas Padjadjaran \\ Jl. Prof. Eyckman No. 38 Bandung 40161 Indonesia \\ Email: fadiyans88@gmail.com
}

\begin{abstract}
Abstrak
Tuberkulosis (TB) merupakan salah satu masalah kesehatan utama pada anak di Indonesia. Diagnosis TB anak sampai saat ini masih cukup sulit. Penegakan diagnosis seharusnya dilakukan dengan pemeriksaan bakteriologis, namun pada anak tidak memungkinkan. Diagnosis TB klinis menjadi acuan saat ini. Penelitian ini adalah penelitian deskriptif, bertujuan untuk memberikan data profil klinis tuberkulosis anak. Data diambil dari rekam medis pasien tuberkulosis anak di poli rawat jalan anak RSHS periode Januari 2016Desember 2016. Subjek penelitian berjumlah 104, diperoleh melalui metode simple random sampling. Dari 104 pasien TB anak, $64(61,54 \%)$ didiagnosis TB paru dan $40(38,46 \%)$ TB ekstraparu. Kontak dengan sumber penularan ditemukan pada 33 pasien (60\%). Gejala klinis TB yang dilihat pada penelitian ini adalah demam $\geq 2$ minggu (62,5\%), berat badan sulit naik (49\%), pembesaran kelenjar limfe (36,5\%), batuk $\geq 2$ minggu (14,4\%), sesak $(7,7 \%)$, pembengkakan tulang (4\%), dan keringat malam (2\%). Disimpulkan bahwa gejala klinis yang paling sering ditemukan pada penelitian ini berturut-turut adalah demam $\geq 2$ minggu, berat badan sulit naik, pembesaran kelenjar limfe, batuk $\geq 2$ minggu, sesak, pembengkakan tulang, dan keringat malam.
\end{abstract}

Kata Kunci: Gejala klinis, tuberkulosis, infeksi tuberkulosis anak. 


\section{Pendahuluan}

Tuberkulosis (TB) merupakan penyakit infeksi yang disebabkan oleh bakteri Mycobacterium tuberculosis. Tuberkulosis masih berada di urutan pertama penyebab kematian akibat penyakit infeksi. Data dari WHO menyebutkan bahwa setiap tahun sembilan juta orang menderita TB, dan sebanyak dua juta orang meninggal akibat penyakit TB. Dari sembilan juta orang yang menderita TB, sebanyak satu juta $(11,0 \%)$ adalah anak-anak di bawah umur 15 tahun. ${ }^{1}$

Indonesia merupakan negara dengan kasus TB terbanyak di dunia setelah India. ${ }^{2}$ Proporsi kasus TB pada anak di antara semua kasus TB di Indonesia pada tahun 2012 sebesar 8,2\% dan Jawa Barat menyumbangkan $14.2 \%$ dari total kasus TB anak di Indonesia. ${ }^{3}$ Pada tahun 2015 proporsi kasus TB anak di Indonesia mencapai 9\%. ${ }^{4}$ Provinsi Jawa Barat termasuk lima provinsi dengan $\mathrm{TB}$ paru tertinggi. Indikator yang sering digunakan untuk penanggulangan TB adalah Case Detection Range (CDR). Angka CDR di Provinsi Jawa Barat sebesar $85 \%$ pada tahun 2009. Data ini menunjukkan bahwa pencapaian CDR masih di bawah target yang ditetapkan yaitu $90 \% .^{3}$

Tuberkulosis anak terjadi pada anak rentang usia 0-14 tahun. ${ }^{4}$ Infeksi TB lima tahun pertama pada anak sering menyebabkan komplikasi. Menurut Wallgren, ada tiga bentuk dasar TB paru pada anak, yaitu penyebaran limfohematogen, TB endobronkial, dan TB paru kronik. Sebanyak 0,5-3\% penyebaran limfohematogen akan menjadi TB milier atau meningitis TB. Tuberkulosis endobronkial (lesi segmental yang timbul akibat pembesaran kelenjar regional) dapat terjadi dalam waktu yang lebih lama (3-9 bulan). Tuberkulosis paru kronik biasanya terjadi akibat reaktivasi kuman di dalam lesi yang tidak mengalami resolusi sempurna. Tuberkulosis ekstrapulmonal dapat terjadi pada 25-30\% anak yang terinfeksi TB. ${ }^{5}$

Sebagai salah satu negara yang menyumbang $60 \%$ dari insidensi terjadinya $\mathrm{TB}^{2}$, sudah sewajarnya Indonesia melakukan usaha dalam penurunan angka kejadian TB di Indonesia. Selain itu, angka kejadian TB yang masih tinggi di Indonesia, menunjukkan bahwa ada yang belum maksimal dari usaha penanganan $\mathrm{TB}$, baik itu dari sisi pencegahan maupun pengobatan sedangkan informasi mengenai profil klinis tuberkulosis anak belum banyak dilaporkan. Penelitian ini bertujuan untuk menyampaikan data profil klinis tuberkulosis anak yang sangat diperlukan sebagai salah satu upaya preventif dan promotif serta dapat digunakan untuk meninjau kembali kesesuaian gejala yang digunakan dalam sistem skoring di Indonesia dengan gejala yang sering muncul pada pasien. 


\section{Metode}

Penelitian dilakukan dari bulan Agustus 2016 - Juni 2017, menggunakan desain deskriptif. Data diambil dengan metode simple random sampling dari data rekam medis pasien TB anak di poli rawat jalan anak Rumah Sakit Dokter Hasan Sadikin periode Januari 2016 Desember 2016. Adapun kriteria eksklusi berupa data rekam medis yang tidak lengkap dan pasien terinfeksi HIV. Variabel penelitian ini meliputi karakteristik pasien (usia, jenis kelamin, status gizi, status pembayaran), jenis tuberkulosis, adanya kontak tuberkulosis, manifestasi klinis yang timbul pada pasien, foto toraks, komorbiditas pasien, hasil tes BTA, kultur MTB, FNA-B, Gene Xpert, dan uji tuberkulin, serta hasil perawatan.

Pengumpulan data dilakukan setelah mendapat izin dari Komisi Etik Penelitian Kesehatan Fakultas Kedokteran Universitas Padjadjaran SK no. 353/UN6.C.10/PN/2017 dan Direktorat Jenderal Pelayanan Kesehatan RSUP Dr.Hasan Sadikin Bandung SK no. LB.02.01/X.2.2.1/9995/2017. Data dianalisis dengan cara deskriptif, menghitung jumlah dan persentase, lalu disajikan dalam bentuk tabel untuk menggambarkan variabel-variabel yang diteliti.

\section{Hasil}

Pada penelitian diambil sebanyak 104 data rekam medis pasien yang tercatat sebagai pasien di poli rawat jalan anak RSHS tahun 2016.

Tabel 1 Jenis Tuberkulosis

\begin{tabular}{lcc}
\hline & \multicolumn{2}{c}{ Jenis Tuberkulosis } \\
\cline { 2 - 3 } Variabel & Jumlah & Persentase (\%) \\
\hline TB Paru & 64 & 61,54 \\
TB Ekstraparu & 40 & 38,46 \\
\hline
\end{tabular}

Tabel 1 menunjukkan jenis TB yang paling sering dialami pasien. Dari 104 data pasien, $61.54 \%$ di antaranya mengalami TB paru dan sisanya mengalami TB ekstraparu.

Tabel 2 Jenis Tuberkulosis Ekstraparu

\begin{tabular}{lcc}
\hline \multirow{2}{*}{ Variabel } & \multicolumn{2}{c}{ Tuberkulosis Ekstra Paru } \\
\cline { 2 - 3 } & Jumlah & Persentase $(\%)$ \\
\hline Limfadenitis TB & 18 & 45 \\
Meningoencepalitis TB & 8 & 20 \\
TB milier & 7 & 17,5 \\
Spondilitis TB & 5 & 12,5 \\
TB abdomen & 1 & 2,5 \\
TB skeletal & 1 & 2,5 \\
\hline
\end{tabular}


Tabel 2 menunjukkan jenis TB ekstraparu yang paling banyak dialami pasien. Sebagian besar pasien TB ekstraparu mengalami limfadenitis TB (45\%), diikuti oleh meningoencepalitis TB (20\%), TB milier (17,5\%), spondilitis TB (7,5\%), TB abdomen (2,5\%), dan TB skeletal $(2,5 \%)$.

Tabel 3 Karakteristik Pasien

\begin{tabular}{lcc}
\hline Parameter & Jumlah & Persentase (\%) \\
\hline Jenis Kelamin & & \\
Laki-laki & 64 & 61,5 \\
Perempuan & 40 & 38,5 \\
\hline Kelompok Usia & & \\
$0-4$ & 46 & 44,2 \\
$5-14$ & 58 & 55,8 \\
\hline Faktor komorbiditas & & \\
Penyakit imun & 2 & 2 \\
Lain-lain & 38 & 36,5 \\
Tidak ada & 64 & 61,5 \\
\hline Kontak TB & & \\
Diketahui & 55 & 53 \\
$\quad-$ Ada & 33 & 60 \\
- Disangkal & 22 & 40 \\
Tidak Diketahui & 49 & 47 \\
\hline Status Gizi & & \\
Malnutrisi Berat & 25 & 24 \\
Malnutrisi Sedang & 10 & 66 \\
Tanpa Malnutrisi & 69 & \\
\hline
\end{tabular}

Tabel 3 menunjukkan karakteristik pasien TB dimana pada jumlah pasien laki-laki $(61,5 \%)$ lebih banyak daripada perempuan $(38,5 \%)$. Kelompok usia 5-14 (55,8\%) tahun lebih sering terjadi dibandingkan 0-4 tahun (44,2\%). Sebanyak 60\% pasien TB diketahui terkena kontak TB. Faktor komorbiditas yang paling sering terjadi adalah berbagai macam penyakit di luar penyakit imunitas yaitu sebanyak $36,5 \%$. Sebanyak $66 \%$ pasien TB tidak mengalami malnutrisi sedangkan 24\% pasien TB mengalami malnutrisi berat.

Tabel 4 Temuan Klinis, Temuan Laboratoris, dan Gambaran Radiologis Pasien TB Anak

\begin{tabular}{lcc}
\hline Parameter & Jumlah & Persentase (\%) \\
\hline Gejala tanda klinis & & \\
Demam $\geq 2$ minggu & 65 & 62,5 \\
Batuk $\geq 2$ minggu & 15 & 14,4 \\
Pembesaran kelenjar limfe & 38 & 36,5 \\
Pembengkakan tulang & 4 & 4 \\
BB sulit naik & 51 & 49 \\
Sesak & 8 & 7,7 \\
Keringat malam & 2 & 2 \\
\hline Foto toraks & & 66,3 \\
Tercantum dalam rekam medis & 69 & 27,5
\end{tabular}




\begin{tabular}{|c|c|c|}
\hline Parameter & Jumlah & Persentase (\%) \\
\hline Gambaran sugestif TB & 50 & 72,5 \\
\hline Tidak tercantum dalam rekam medis & 35 & 33,7 \\
\hline \multicolumn{3}{|l|}{ BTA } \\
\hline Diperiksa & 15 & 14,4 \\
\hline - Positif & 4 & 26,7 \\
\hline - Negatif & 11 & 73,3 \\
\hline Tidak diperiksa & 89 & 85,6 \\
\hline \multicolumn{3}{|l|}{ Sputum MTB } \\
\hline Diperiksa & 15 & 14,4 \\
\hline - Positif & 4 & 26,7 \\
\hline - Negatif & 11 & 73,3 \\
\hline Tidak diperiksa & 89 & 85,6 \\
\hline \multicolumn{3}{|l|}{ FNA-B } \\
\hline Diperiksa & 19 & 18,3 \\
\hline - Positif & 19 & 100,0 \\
\hline - Negatif & 0 & 0 \\
\hline Tidak diperiksa & 85 & 81,7 \\
\hline \multicolumn{3}{|l|}{ Gene Xpert } \\
\hline Diperiksa & 21 & 20,2 \\
\hline - Positif & 7 & 33,3 \\
\hline - Negatif & 14 & 66,7 \\
\hline Tidak diperiksa & 83 & 79,8 \\
\hline \multicolumn{3}{|l|}{ Uji tuberculin } \\
\hline Diperiksa & 61 & 58,7 \\
\hline - Positif & 43 & 70,5 \\
\hline - Negatif & 18 & 29,5 \\
\hline Tidak diperiksa & 43 & 41,3 \\
\hline
\end{tabular}

Tabel 4 menunjukkan temuan klinis, temuan laboratoris, dan gambaran radiologis pasien TB anak dimana gejala yang paling sering muncul pada pasien TB adalah demam $(62,5 \%)$, berat badan sulit naik (49\%), pembesaran kelenjar limfe (36,5\%), batuk $\geq 2$ minggu $(14,4 \%)$, sesak $(7,7 \%)$, pembengkakan tulang $(4 \%)$, dan keringat malam $(2 \%)$.

Foto toraks pada pasien TB 72,5\% menunjukkan hasil sugestif TB. Pemeriksaan BTA dan sputum MTB lebih banyak tidak diperiksa pada pasien anak (85,6\%) menunjukkan hasil negatif sebanyak 73,33\%, begitu pula untuk pemeriksaan FNA-B dan Gene Xpert. FNA-B yang diperiksakan sebanyak 18,3\% dan menunjukkan hasil 100\% positif sedangkan Gene Xpert yang diperiksakan 20,2\% dan menunjukkan hasil 66,7\% negatif. Hasil uji tuberkulin pada pasien TB menunjukkan positif pada $70,5 \%$ pasien yang diperiksakan $(58,7 \%)$.

\section{Diskusi}

Pada penelitian diambil sebanyak 104 data rekam medis pasien yang tercatat sebagai pasien di poli rawat jalan anak RSHS tahun 2016 periode Januari 2016 hingga Desember 2016 dengan menggunakan teknik simple random sampling. Berdasarkan tabel 1, sebanyak 61,54\% diantaranya mengalami TB paru dan sisanya mengalami TB ekstraparu. Rahajoe NN dkk juga 


\section{Research Article}

menyatakan bahwa jenis TB tersering pada anak adalah TB paru. ${ }^{6}$ Tabel 2 menunjukkan jenis TB ekstraparu yang paling banyak dialami pasien. Sebagian besar pasien TB ekstraparu mengalami limfadenitis TB (45\%), diikuti oleh meningoencepalitis TB (20\%), TB milier (17,5\%), spondilitis TB (7,5\%), TB abdomen (2,5\%), dan TB skeletal (2,5\%). Hal ini sesuai dengan penelitian Rezeki dkk yang menyatakan bahwa Limfadenitis tuberkulosis merupakan tuberkulosis ekstraparu yang paling sering ditemukan. ${ }^{7}$

Informasi yang terdapat pada tabel 3 menjelaskan bahwa jumlah pasien laki-laki $(61,5 \%)$ lebih banyak daripada perempuan $(38,5 \%)$. Kelompok usia 5-14 (55,8\%) tahun lebih sering terjadi TB dibandingkan 0-4 tahun (44,2\%). Hasil temuan usia 5-14 tahun yang lebih banyak dibandingkan usia 0-4 tahun tidak sesuai dengan penelitian Oktaviani, yang sebagian besar kasus tuberkulosis anak terjadi pada umur kurang dari 5 tahun, namun hal ini didukung pada penelitian yang dilakukan oleh Nurwitasari dkk dimana Mayoritas kasus tuberkulosis anak banyak terjadi pada anak usia lebih dari 5 tahun. ${ }^{8,9}$ Data lain yang juga mendukung adalah hasil penelitian Kertasasmita dengan peningkatan kasus TB paling banyak terjadi pada usia 25-44 tahun sebesar 54,5\%, diikuti oleh 5-12 tahun sebesar 38,1\%, dan usia 0-4 tahun sebesar $36,1 \%{ }^{1}$

Jumlah pasien laki-laki yang lebih banyak daripada perempuan sesuai dengan penelitian yang diadakan oleh Nurwitasari dkk dan hasil survei prevalensi tuberkulosis yang dilakukan oleh departemen kesehatan dimana jumlah kasus TB pada laki-laki lebih banyak 1,5 kali dibandingkan perempuan. ${ }^{9,11}$ Selain itu, data dari rekam medis di poli rawat jalan RSHS 2016 juga menunjukkan bahwa jumlah pasien TB anak laki-laki berjumlah 225 pasien, lebih banyak dari pasien TB anak perempuan berjumlah 179 pasien. ${ }^{10}$ Sebanyak $60 \%$ pasien TB diketahui terdapat kontak TB. Hal ini didukung oleh hasil penelitian Diani dkk yang menunjukkan bahwa tingginya prevalensi tuberkulosis pada anak sebagian besar terjadi pada anak yang pernah mengalami kontak atau tinggal bersama dengan penderita tuberkulosis dewasa ${ }^{12}$

Faktor komorbiditas yang paling sering terjadi adalah berbagai macam penyakit diluar penyakit imunitas yaitu sebanyak $36,5 \%$. Sebanyak $24 \%$ pasien TB mengalami malnutrisi berat. Malnutrisi dan tuberkulosis merupakan dua hal yang saling berkesinambungan, malnutrisi dapat meningkatkan risiko terjadinya tuberkulosis dan pasien tuberkulosis dengan malnutrisi memiliki masa pemulihan yang lebih lambat dan tingkat kematian yang lebih tinggi dibandingkan pasien dengan status gizi normal. ${ }^{13}$ Namun, mesikpun malnutrisi dikatakan meningkatkan risiko TB, kenyataannya, hasil data rekam medis menunjukkan 66\% pasien TB tidak mengalami malnutrisi. Hal ini juga terjadi pada penelitian yang dilakukan oleh Soegiarto dkk. ${ }^{14}$ Seseorang 


\section{Research Article}

dengan status gizi baik masih dapat terinfeksi kuman TB apabila mengalami gangguan fungsi imunitas selular salah satunya akibat status mikronutrien yang kurang baik. ${ }^{6}$

Hal ini didukung dengan pernyataan Pryjambodo, bahwa anak dengan intensitas kontak yang lama atau kontak dengan penderita TB lebih dari 6 bulan dengan penderita TB dewasa tetap menyebabkan anak teinfeksi kuman tuberkulosis dan tetap berkembang menjadi infeksi meskipun dalam keadaan status gizi baik. ${ }^{15}$ Status gizi tidak mempengaruhi suatu infeksi dikarenakan infeksi dengan keadaan gizi kurang merupakan hubungan timbal balik atau hubungan sebab akibat. Menurut Arsin dkk, penyakit infeksi dapat memperburuk keadaan gizi dan keadaan gizi kurang dapat mempermudah terjadinya infeksi. ${ }^{16}$

Demam $(62,5 \%)$ menjadi gejala yang paling sering muncul sesuai dengan hasil penelitian Bakhtiar. ${ }^{17}$ Rahajoe NN dkk juga menyatakan bahwa demam merupakan gejala klinis yang paling sering dikeluhkan orangtua, berkisar antara $40 \%-80 \%{ }^{6}$

Keringat malam tidak menjadi patokan dalam sistem skoring TB, namun pada $2 \%$ pasien dari subjek penelitian didapatkan gejala adanya keringat malam, hal ini dapat terjadi karena keringat malam merupakan laporan subjektif yang dilebih-lebihkan dari ritme suhu sirkadian normal. Ritme suhu sirkadian normal mencapai suhu tertinggi pada pukul 6 sore. ${ }^{18}$ Pembesaran kelenjar limfe sering dijumpai terutama pada regio koli anterior, submandibula, supraklavikula, aksila, dan inguinal. Gejala batuk yang jarang terjadi sesuai dengan pernyataan Bakhtiar bahwa sebagian besar TB paru pada anak tidak menunjukkan gejala batuk kronik, kecuali bila terjadi limfadenitis regional yang menekan bronkus sehingga merangsang reseptor batuk. ${ }^{17}$

Foto toraks pada pasien TB 72,5\% menunjukkan hasil sugestif TB. Hal ini sesuai dengan penelitian di Iran dimana 71,5\% penderita TB paru menunjukkan gambaran sugestif TB.

${ }^{19}$ Pemeriksaan BTA dan sputum MTB lebih banyak tidak diperiksa pada pasien anak $(85,6 \%)$ menunjukkan hasil negatif sebanyak 73,33\%. Hal ini didukung dengan hasil survei Kementerian Kesehatan terhadap proporsi kasus tuberkulosis paru terkonfirmasi bakteriologis di tahun 20082015 yang menunjukkan bahwa hasil belum mencapai target yang diharapkan (70\%) sehingga mengindikasikan bahwa diagnosis kurang memberikan prioritas untuk menemukan pasien yang menular di Indonesia. ${ }^{11}$

Hasil pemeriksaan BTA dan sputum anak yang negatif disebabkan karena kuman TB sangat jarang ditemukan di dalam sekret endobronkial pasien anak seperti yang dijelaskan oleh Rahajoe dkk, beliau menjelaskan bahwa jumlah kuman pada TB anak pada umumnya sedikit, namun karena imunitas anak masih lemah, jumlah yang sedikit tersebut sudah mampu menyebabkan sakit. Kemudian, lokasi infeksi primer yang kemudian berkembang menjadi sakit 


\section{Research Article}

TB primer biasanya terjadi di daerah parenkim yang jauh dari bronkus, sehingga tidak terjadi produksi sputum dan tidak ada/sedikitnya produksi sputum sehingga menyebabkan jarang terjadinya gejala batuk pada pasien TB anak. ${ }^{6}$ Begitu pula untuk pemeriksaan FNA-B dan Gene Xpert.

Fine needle aspiration biopsy (FNA-B) yang diperiksakan sebanyak 18,3\% dan menunjukkan hasil 100\% positif sedangkan Gene Xpert yang diperiksakan 20,2\% dan menunjukkan hasil $66.7 \%$ negatif. Berdasarkan hasil pengolahan data, tes FNA-B lebih banyak dilakukan kepada pasien TB ekstraparu dengan spesifikasi TB limfadenitis, hal ini dikarenakan diagnosa limfadenitis TB mudah ditegakkan apabila gambaran-gambaran khas ditemukan pada sediaan aspirasi, untuk membedakan limfadenitis akut supuratif atau limfadenitis TB supuratif. ${ }^{20}$

Hasil uji tuberkulin pada pasien TB menunjukkan positif pada $70,5 \%$ pasien yang diperiksakan (58,7\%). Tuberkulin mempunyai sensivitas cukup tinggi, yaitu 80-96\%. Namun, terdapat sejumlah faktor dapat menyebabkan hasil uji tuberkulin negatif. Karena itu, hasil uji tuberkulin negatif tidak menyingkirkan diagnosis TB. Faktor-faktortersebut antara lain dalam masa inkubasi, setelah mendapat vaksin hidup, campak, pertusis, keganasan, dan malnutrisi berat. $^{17}$

\section{Simpulan}

Gejala klinis yang paling sering ditemukan pada pasien TB anak berturut-turut adalah demam $\geq 2$ minggu, berat badan sulit naik, pembesaran kelenjar limfe, batuk $\geq 2$ minggu, sesak, pembengkakan tulang, dan keringat malam. Saran untuk penelitian selanjutnya adalah jumlah sampel lebih besar agar hasil dapat dianalisis lebih akurat.

\section{Daftar Pustaka}

1. Kartasasmita CB. Epidemiologi Tuberkulosis. Sari Pediatri. 2009; 11(2). [Online].; 2009. [Cited: 2016 Oct 22]. Available from: https://www.researchgate.net/publication/312301356_Epidemiologi_Tuberkulosis.

2. WHO. World Health Organization Global Tuberculosis Report 2016. [Online].; 2016. [Cited: 2016 Oct 22]. Available from: http://www.who.int/tb/publications/global_report/en/.

3 Kementerian Kesehatan Republik Indonesia. Strategi Nasional Pengendalian TB di Indonesia 2010 - 2014. [Online].; 2011. [Cited: 2016 Oct 22]. Available from: http://www.searo.who.int/indonesia/topics/tb/stranas_tb-2010-2014.pdf.

4. Kementerian Kesehatan Republik Indonesia. Petunjuk Teknis Manajemen dan Tatalaksana TB Anak. [Online].; 2016. [Cited: 2016 Oct 22]. Available from: http://www.tbindonesia.or.id/tbident/uploads/2017/02/Buku-Petunjuk-TeknisManajemen-dan-Tatalaksana-TB-Anak.pdf .

5. Werdhani RA. Patofisiologi, Diagnosis, dan Klasifikasi Tuberkulosis. [Online].; 2016. [Cited: 2016 Oct 22]. Available from: http://staff.ui.ac.id/system/files/users/retno.asti/material/patodiagklas.pdf .

6. Raharjoe NN, Basir D, MS Makmuri, Kartasasmita CB. Pedoman Nasional Tuberkulosisis Anak Jakarta: UKK Respirologi PP Ikatan Dokter Anak Indonesia; 2007. [Online].; 2014. [Cited: 2016 Oct 22]. Available from : https://saripediatri.org/index.php/sari-pediatri.

7. Rezeki M, Parwati I, Hernowo BS, Tjandrawati A. Validitas Multiplex Real Time Polymerase Chain Reaction untuk Diagnosis Limfadenitis Tuberkulosis pada Spesimen Blok Parafin. Majalah Kedokteran Bandung. 2014; 64(3). [Online].; 2014. [Cited: 2016 Oct 22]. Available from: http://journal.fk.unpad.ac.id/index.php/mkb/article/view/314. 


\section{Research Article}

8. Oktaviani D. Hubungan Kepatuhan Minum Obat Anti Tuberkulosis dengan Status Gizi Anak Penderita Tuberkulosis Paru.: Diponegoro University; 2011 [Tesis]. [Cited: 2016 Oct 22]. Available from: http://eprints.undip.ac.id/32598/1/396_Dini_Oktaviani_G2C007023.pdf .

9. Nurwitasari A, Wahyuni CU. The Effect of Nutritional Status and Contact History toward Childhood Tuberculosis in Jember. Jurnal Berkala Epidemiologi. 2015 Mei; 3(2). [Online].; 2015. [Cited: 2016 Oct 22]. Available from: https://ejournal.unair.ac.id/JBE/article/view/1658.

10. RSUP Dr. Hasan Sadikin. Jumlah Pengunjung Pasien Rawat Jalan Periode 2016. Bandung: RSUP Dr. Hasan Sadikin, Instalasi Rekam Medis. 2016.

11. Kementerian Kesehatan RI. Profil Kesehatan Indonesia Tahun 2015. Jakarta; 2015. [Online].; 2015. Available from: http://www.depkes.go.id/resources/download/pusdatin/profil-kesehatan-indonesia/profil-kesehatan-Indonesia-2015.pdf

12. Diani A, Setyanto DB, Nurhamza W. Proporsi Infeksi Tuberkulosis dan Gambaran Faktor Risiko pada Balita yang Tinggal dalam Satu Rumah dengan Pasien Tuberkulosis Paru Dewasa. Sari Pediatri. 2011; 13(1). [Online].; 2011. [Cited: 2016 Oct 22]. Available from: https://saripediatri.org/index.php/sari-pediatri/article/view/460.

13. Gupta K, Gupta R, Atreja A, Verma M, Vishvkarma S. Tuberculosis and Nutrition. Lung India. 2009; 26(1). [Online].; 2009. [Cited: 2016 Oct 22]. Available from: http://www.lungindia.com/article.asp?issn=09702113; year $=2009$; volume $=26$; issue $=1$; spage $=9$; epage $=16$; aulast $=$ Gupta.

14. Soegiarto B, Boediman I, Munasir Z. Kadar Seng Plasma Pasien Tuberkulosis Anak. Sari Pediatri. 2008; 10(4) [Online].; 2009. [Cited: 2016 Nov 13]. Available from: https://www.researchgate.net/publication/312260693_Kadar_Seng_Plasma_Pasien_Tuberkulosis_Anak_Studi_Pendah uluan.

15. Pryjambodo M. Hubungan antara Kadar Seng (Zn) Serum dengan Skor Tuberkulosis Paru Anak.: Universitas Diponegoro; 2011 [Tesis]. [Cited: 2016 Oct 23]. Available from: http://eprints.undip.ac.id/28844/ .

16. Arsin AA, W, Ansar J. Gambaran Asupan Zat Gizi dan Status Gizi Penderita TB Paru di Kota Makasar.: Universitas Hasanuddin; 2012. [Cited: 2016 Oct 23]. Available from: http://repository.unhas.ac.id/bitstream/handle

17. Bakhtiar. Pendekatan Diagnosis Tuberkulosis Pada Anak di Sarana Pelayanan Kesehatan Dengan Fasilitas Terbatas. Jurnal Kedokteran Syiah Kuala. 2016; 16(2). [Online].; 2016. [Cited: 2016 Nov 13]. Available from: http://jurnal.unsyiah.ac.id/JKS/article/view/5336.

18. Perry, Anne G, Patricia A. Buku Ajar Fundamental Keperawatan (Konsep, Proses, dan Praktik). Jakarta; 2011. [Online].; 2011. [Cited: 2016 Oct 23]. Available from: http://kink.onesearch.id/Record.

19. Pazoki M, Paknejad O, Khashayar P, Eshraghian MR, Bastani, Ghafari F. Comparing Chest Radiograph and Tuberculin Skin Test in Children. Acta Medica Iranica. 2008; 47(4). [Online].; 2009. [Cited: 2016 Nov 13]. Available from: http://acta.tums.ac.ir/index.php/acta/article/view/3592.

20. Eliandy S, Lubis MND, D. Hubungan Gambaran Bercak-Bercak Gelap (Dark Specks) pada Latar Belakang Material Nekrotik Granular Eosinofilik dengan Kadar CD4 Penderita Limfadenitis Tuberkulosis Servikalis yang Disertai HIV/AIDS. Majalah Patologi Indonesia. 2011. 20(3). [Online].; 2011. [Cited: 2016 Nov 13]. Available from: https://id.123dok.com/document/ky6e1k7z-hubungan-gambaran-bercak-bercak-gelap-dark-specks-pada-latarbelakang-material-nekrotik-granular-eosinofilik-dengan-kadar-cd4-penderita-limfadenitis-tuberkulosis-servikalisyang-disertai-hiv-aids.html. 